\title{
The Composition of Urban Storm-Water Runoff Pollutants in Sediment and Loess Soil in Rain Garden
}

\author{
Chao Guo ${ }^{1,2,3,4}$, Jiake Li ${ }^{4 *}$, Huaien $\mathrm{Li}^{4}$ \\ ${ }^{1}$ Shaanxi Provincial Land Engineering Construction Group, Key Laboratory of Degraded \\ and Unused Land Consolidation Engineering, Ministry of Natural Resources \\ ${ }^{2}$ Shaanxi Provincial Land Engineering Construction Group, Shaanxi Provincial Land Consolidation \\ Engineering Technology Research Center \\ ${ }^{3}$ Shaanxi Provincial Land Engineering Construction Group, Land Engineering Technology Innovation Center, \\ Ministry of Natural Resources \\ ${ }^{4}$ State Key Laboratory of Eco-hydraulics in Northwest Arid Region of China, \\ Xi'an University of Technology, Xi'an 710048, China
}

Received: 14 March 2020

Accepted: 5 September 2020

\begin{abstract}
Many studies have demonstrated the importance of the volume reduction and pollutants purification effect of rain gardens. However, the pollutants variations in sediment of rainfall runoff and soil of rain gardens have been rarely explored. In this study, three rain gardens were conducted from April to October 2018 to investigate the pollutants composition of urban stormwater runoff in sediment and soil. The results show that: 1) $\mathrm{NO}_{2}-\mathrm{N}$ and TON were the main forms in the sediments, but for soil, they were $\mathrm{NO}_{3}-\mathrm{N}$ and TON.NH${ }_{3}-\mathrm{N}, \mathrm{NO}_{2}-\mathrm{N}, \mathrm{TON}, \mathrm{TN}, \mathrm{SRP}$ and TP in the sediment were all greater than those in soil, and they were 4.54, 5.0, 2.01, 1.33, 4.1, 14.3 and 2.21, 3.25, 1.62, 1.11,2.5, 5.3 times greater in sediment than those in soil. However, less $\mathrm{NO}_{3}-\mathrm{N}$ content was observed in the sediment. 2) $\mathrm{Cu}, \mathrm{Zn}$ and $\mathrm{Cd}$ in sediment were extremely greater than those in soil. $\mathrm{Cu}$ was 22.47 and 4.02 times greater in sediment than that in soil, which were 18.93, 6.11 and 4.60, 8.57 times for $\mathrm{Zn}$ and $\mathrm{Cd}$. 3) the N, P, TOC and heavy metals contents had a good linear relationship with the activity of enzymes, and the $\mathrm{R}^{2}$ were all more than 0.66 .
\end{abstract}

Keywords: stormwater runoff, N, P, heavy metals, sediment, loess soil, rain garden

*e-mail: xaut_ljk@163.com 


\section{Introduction}

Rapid urban expansion leads to the replacement of native vegetation areas, which provide rainwater interception, storage, and infiltration functions, with impervious surfaces, which often results in an increase in the rate and volume of surface runoff of rainwater [1]. Therefore, urban stormwater has become an increasingly important source of pollutants to receiving waters [2]. Excess pollutants, such as nitrogen, phosphorus and heavy metals, input to aquatic ecosystems cause eutrophication, which leads to alterations in community structure, degradation of habitat quality, and increased incidences and duration of harmful algal blooms [3-4]. Stormwater nitrogen and phosphorus are present in a number of chemical forms, including ammonium $\left(\mathrm{NH}_{3}-\mathrm{N}\right)$, nitrate $\left(\mathrm{NO}_{3}-\mathrm{N}\right)$, nitrite $\left(\mathrm{NO}_{2}-\mathrm{N}\right)$, dissolved organic $\mathrm{N}(\mathrm{DON})$, particulate organic N (PON), soluble reactive phosphorus (SRP), dissolved organic phosphorus (DOP), and dissolved phosphorus (DP), etc [5]. The pollutants composition varies with land use and hydrologic conditions [6]. Nitrogen and phosphorus behavior in stormwater runoff are therefore complex because of the biogeochemical complexity of their species.

Facing the serious problems of logging [7], environment pollution [8] and lack of groundwater recharge caused by traditional urbanization, various stormwater control measures (SCMs) are being employed in watersheds to reduce pollutant loads from stormwater runoff, with rain garden as one of the more effective urban SCMs [9-10]. Rain garden is an infiltration-based SCM that is widely used in residential area because of its ability to improve water quality and the hydrologic condition of the developed landscape. Rain gardens are effective at removing a range of pollutants, including suspended solids, heavy metals, nitrogen, phosphorus, oil and grease [11]. Laboratory and pilot-scale bioretention tank studies have shown that removal efficiencies of $\mathrm{Cu}, \mathrm{Zn}$ and $\mathrm{Pb}$ from a synthetic runoff were typically greater than $95 \%$, those of total phosphorus were approximately $80 \%$, and total nitrogen were $50-70 \%$ [12-13]. However, could the pollutants removed by bioretention tanks kept in soil? Or they could be decomposed fast? We expect that rain water can be effectively purified, meanwhile we do not want pollutants to have great impact on the soil of the facility. In that way, is it possible to set up a pond to sediment rain water before the rainfall runoff enters the rain garden? And the amount of pollutants in the sedimentation tank is not clear now. Soil enzyme activity reflects the intensity and direction of various biochemical processes in soil, and it is one of the most basic properties of soil [14]. Rain garden soil contains different forms of enzymes, and soil enzyme activities are closely related to soil nutrients dynamics [15]. The enzymatic product of soil urease (SU) is ammonia Soil sucrase (SU) is related to soil organic matter, phosphorus content, microbial quantity and soil respiration intensity. Soil protease (SP) mainly involves in the conversion of amino acids, proteins and other protein-containing organic compounds in soil. And soil acid phosphatase (SAP) can accelerate the conversion and hydrolysis of organic phosphorus [16]. Therefore, to determine soil N, P and their relations with enzyme activity in the rain garden are of great significance to understand the mechanism of pollutants purification carried in rainfall runoff. At present, many studies have been conducted on the regulation and pollutants purification effects of rain gardens on rainfall runoff [17-18]. Some researchers focus on the structure, running effect, influence mechanism and model simulation of LID or facility measures themselves [1920]. There are also a few experts have carried out the impact of concentrated infiltration of rainfall runoff on soil facilities in recent years [21-22]. However, the pollutants variations in sediment of inflow weir and soil in rain garden and the contrast of the two have been rarely explored.

Therefore, this paper takes three rain gardens that have been used for many years in Xi'an University of Technology as the study facilities, and the objectives of this study are to (1) contrast the various of nitrogen (ammonia nitrogen- $\mathrm{NH}_{3}-\mathrm{N}$, nitrate nitrogen- $\mathrm{NO}_{3}-\mathrm{N}$, nitrite- $\mathrm{NO}_{2}-\mathrm{N}$, total organic nitrogen-TON and total nitrogen-TN), phosphorus (total phosphorus-TP, soluble reactive phosphorus-SRP) and total organic carbonTOC in sediments and rain garden soil; (2) study the influence of stomwater concentration on heavy metals (copper- $\mathrm{Cu}$, zinc- $\mathrm{Zn}$ and cadmium-Cd) and enzyme activity (urease-SU, sucrose-SS, acid phosphatasePPS and protease-PS) in sediments and rain garden soil; (3) analyze the quantitative relationship between soil N, P, TOC, heavy metal contents and soil enzyme. Conclusions from related research can provide important theoretical support for further study of LID facilities, and will provide scientific basis and theoretical support for the rational allocation of concentrated infiltration measures.

\section{Materials and Methods}

\section{Site Description}

Rain gardens in this study located at Xi'an University of Technology, Xi'an, Shaanxi Provence, China. The city of Xi'an is in Northwest China (E107 $40^{\prime}-109^{\circ} 49^{\prime}$ and $\mathrm{N} 33^{\circ} 39^{\prime}-34^{\circ} 45^{\prime}$ ), which has a temperate continental climate. The annual average temperature in Xi'an is $13^{\circ} \mathrm{C}$, and the rainfall is $551 \mathrm{~mm}$, but the evaporation is $990 \mathrm{~mm}$ [23]. More than $80 \%$ of rainfall occurred from May to October. The city is situated on widely distributed loess soil that generally has deep profile of more than $50 \mathrm{~m}$. The soil bulk density is generally $1.35 \mathrm{~g} / \mathrm{cm}^{3}$, comprising $9 \%$ clay, $80 \%$ silt, and $10 \%$ sand. The reported infiltration rate of the loess soil varies from $0.4 \mathrm{~m} / \mathrm{d}$ to $2 \mathrm{~m} / \mathrm{d}$ and higher. This study 


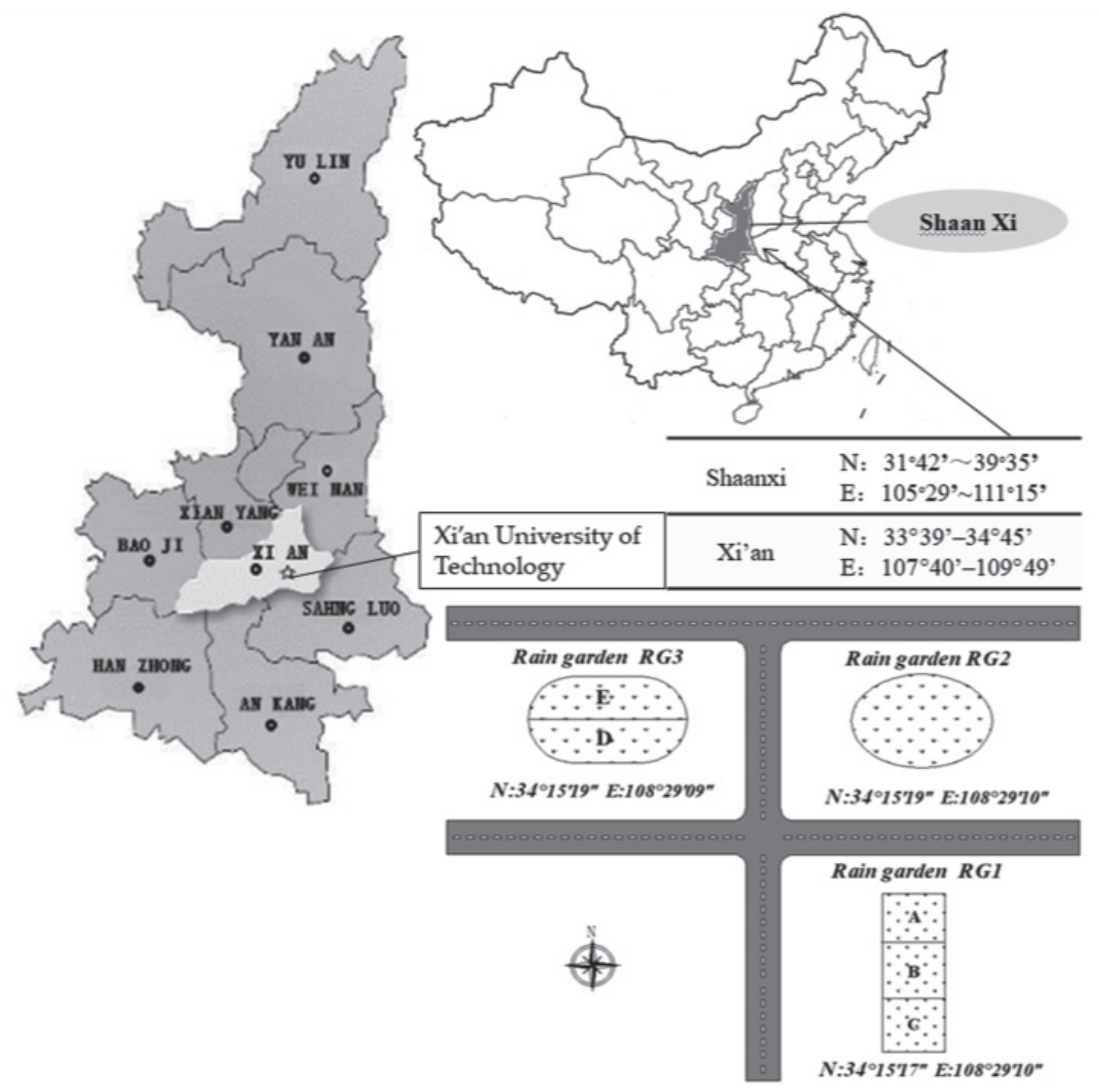

Fig. 1. Location of the experimental rain gardens.

involves three rain gardens of No. 1 (RG1), No. 2 (RG2) and No.3 (RG3), as illustrated in Fig. 1.

\section{Rain Garden of RG1}

RG1 was completed in 2010, and it accepted roof rainfall from a teaching building. RGlincluded three parts, namely, A, B and C, as illustrated in Fig. 1. The confluence area of RG1 was $216 \mathrm{~m}^{2}$, and the confluence area ratio (confluenceratio $=$ confluencearea /garden area) was 6:1. Thunbergiaalata was planted in the rain garden. The bottom of RG1 was laid with waterproof geomembrane, placed with perforated Polyvinyl Chloride (PVC) tube drainage $(\mathrm{d}=110 \mathrm{~mm})$, wrapped in permeable geotextile, and covered with a layer of gravel. Inflow and outflow of the rain garden was measured with pressure transducers mounted on V-notch weirs of $30^{\circ}$ installed at the inlet and outlet of the rain garden. The overall situation of rain gardens was shown in Table 1.

\section{Rain Garden of RG2}

RG2 was built in 2011 and collected stormwater runoff of concrete roof with area of $604.7 \mathrm{~m}^{2}$. The confluence area ratio was 20:1. RG2 was the infiltration facility without outlet. It was oval with $20 \mathrm{~cm}$ loess soil. Tageteserecta L. and Hedera nepalensis var. sinensis (Tobl.) Rehd were planted in the rain garden. Inflow of the rain garden was measured with pressure transducers mounted on V-notch weirs of $45^{\circ}$ installed at the inlet of the rain garden, and overflow was measured with draft mounted on V-notch weirs of $30^{\circ}$. Runoff entered RG2 and infiltrated to recharge the groundwater directly. There is a landfill plant at $5 \mathrm{~m}$ on the east side of RG2, and it is mainly used to collect domestic garbage on campus. The bottom of the landfill plant is concrete with anti-seepage film, and the landfill leachate will not fall vertically or horizontally. A small amount of debris from the debris without cleaning on time would be washed into the garden with runoff.

\section{Rain Garden of RG3}

Rain garden of RG3 was installed in 2012 and treated stormwater runoff from road and concrete roof. It was oval with $60 \mathrm{~cm}$ loess soil. The confluence area ratio was 20:1. The flapper in the middle was used to divide RG2 into the two sub-sections of part D and E. RG3-D was conventionally drained without a saturated zone using a perforated plastic pipes, whereas RG3-E was permeable without outlet. Soil samples in this study were collected in RG3-E. Inflows of RG3-D and $\mathrm{E}$ were measured with pressure transducers mounted on V-notch weirs of $30^{\circ}$ installed at the inlet. They had the same plants as RG2.The structures of three rain gardens were shown in Fig. 2. 
Table 1.The overall situation of rain garden.

\begin{tabular}{|c|c|c|c|c|c|c|c|}
\hline \multicolumn{2}{|c|}{ Rain Gardens } & Size & $\begin{array}{l}\text { BottomTreat- } \\
\text { ment }\end{array}$ & \multicolumn{2}{|c|}{ Filters and Thickness } & $\begin{array}{l}\text { Confluence } \\
\text { Area Ratio }\end{array}$ & $\begin{array}{l}\text { Underlying } \\
\text { Surface }\end{array}$ \\
\hline \multirow{13}{*}{ RG1 } & \multirow{3}{*}{ A } & \multirow{3}{*}{$\begin{array}{l}\text { Length } \times \text { Width } \times \text { Height } \\
\quad=4 \mathrm{~m} \times 3 \mathrm{~m} \times 0.9 \mathrm{~m}\end{array}$} & \multirow{3}{*}{ Waterproof } & Aquifer layer & $20 \mathrm{~cm}$ & \multirow{13}{*}{$6: 1$} & \multirow{13}{*}{ Roof } \\
\hline & & & & Loess soil & $55 \mathrm{~cm}$ & & \\
\hline & & & & Gravel & $15 \mathrm{~cm}$ & & \\
\hline & \multirow{5}{*}{ B } & \multirow{5}{*}{$\begin{array}{l}\text { Length } \times \text { Width } \times \text { Height } \\
\quad=4 \mathrm{~m} \times 3 \mathrm{~m} \times 0.9 \mathrm{~m}\end{array}$} & \multirow{5}{*}{ Waterproof } & Aquifer layer & $20 \mathrm{~cm}$ & & \\
\hline & & & & Loess soil & $20 \mathrm{~cm}$ & & \\
\hline & & & & Silver sand & $20 \mathrm{~cm}$ & & \\
\hline & & & & Coarse sand & $15 \mathrm{~cm}$ & & \\
\hline & & & & Gravel & $15 \mathrm{~cm}$ & & \\
\hline & \multirow{5}{*}{$\mathrm{C}$} & \multirow{5}{*}{$\begin{array}{l}\text { Length } \times \text { Width } \times \text { Height } \\
\quad=4 \mathrm{~m} \times 3 \mathrm{~m} \times 0.9 \mathrm{~m}\end{array}$} & \multirow{5}{*}{$\begin{array}{c}\text { Waterproof } \\
\text { Flooded height } \\
15 \mathrm{~cm}\end{array}$} & Aquifer layer & $20 \mathrm{~cm}$ & & \\
\hline & & & & Loess soil & $20 \mathrm{~cm}$ & & \\
\hline & & & & Silver sand & $20 \mathrm{~cm}$ & & \\
\hline & & & & Coarse sand & $15 \mathrm{~cm}$ & & \\
\hline & & & & Gravel & $15 \mathrm{~cm}$ & & \\
\hline \multirow{2}{*}{\multicolumn{2}{|c|}{ RG2 }} & \multirow{2}{*}{$\begin{array}{l}\text { Long axis } \times \text { Short axis } \times \text { Depth } \\
\quad=7 \mathrm{~m} \times 5.5 \mathrm{~m} \times 0.35 \mathrm{~m}\end{array}$} & \multirow{2}{*}{ Permeable } & Aquifer layer & $20 \mathrm{~cm}$ & \multirow{2}{*}{$20: 1$} & \multirow{2}{*}{ Roof } \\
\hline & & & & Loess soil & $20 \mathrm{~cm}$ & & \\
\hline \multirow{4}{*}{ RG3 } & \multirow{2}{*}{$\mathrm{D}$} & \multirow{2}{*}{$\begin{array}{l}\text { Long axis } \times \text { Short axis } \times \text { Depth } \\
\quad=6 \mathrm{~m} \times 2 \mathrm{~m} \times 1.1 \mathrm{~m}\end{array}$} & \multirow{2}{*}{ Waterproof } & Aquifer layer & $50 \mathrm{~cm}$ & \multirow{4}{*}{$15: 1$} & \multirow{4}{*}{$\begin{array}{l}\text { Roof and } \\
\text { concrete } \\
\text { pavement }\end{array}$} \\
\hline & & & & Loess soil & $60 \mathrm{~cm}$ & & \\
\hline & \multirow{2}{*}{$\mathrm{E}$} & \multirow{2}{*}{$\begin{array}{c}\text { Long axis } \times \text { Short axis } \times \text { Depth } \\
=6 \mathrm{~m} \times 2 \mathrm{~m} \times 1.1 \mathrm{~m}\end{array}$} & \multirow{2}{*}{ Permeable } & Aquifer layer & $50 \mathrm{~cm}$ & & \\
\hline & & & & Loess soil & $60 \mathrm{~cm}$ & & \\
\hline
\end{tabular}

\section{Water Test Methods}

Inflow and outflow were recorded during the period of rainfall, and water samples were collected immediately. The samples were stored in a refrigerator at $-4^{\circ} \mathrm{C}$, and analysis was completed within 5 days. $\mathrm{NH}_{3}-\mathrm{N}$ and $\mathrm{NO}_{3}-\mathrm{N}$ were measured by continuous flowing analysis (SKALAR, Holland). TN and TP were measured by ultraviolet spectrophotometer (DR5000, Hach Company, Colorado, USA). And the weighing method was used to measure TSS. Heavy metals were determined by atomic absorption spectrophotometry. Water samples were mainly used to analyze the pollutants load entering the rain gardens.

\section{Soil Samples Collection}

Sediment sludge was collected in the inflow weir of the three rain gardens, and they were found to be black and smelly. The soil samples were collected in RG2 and
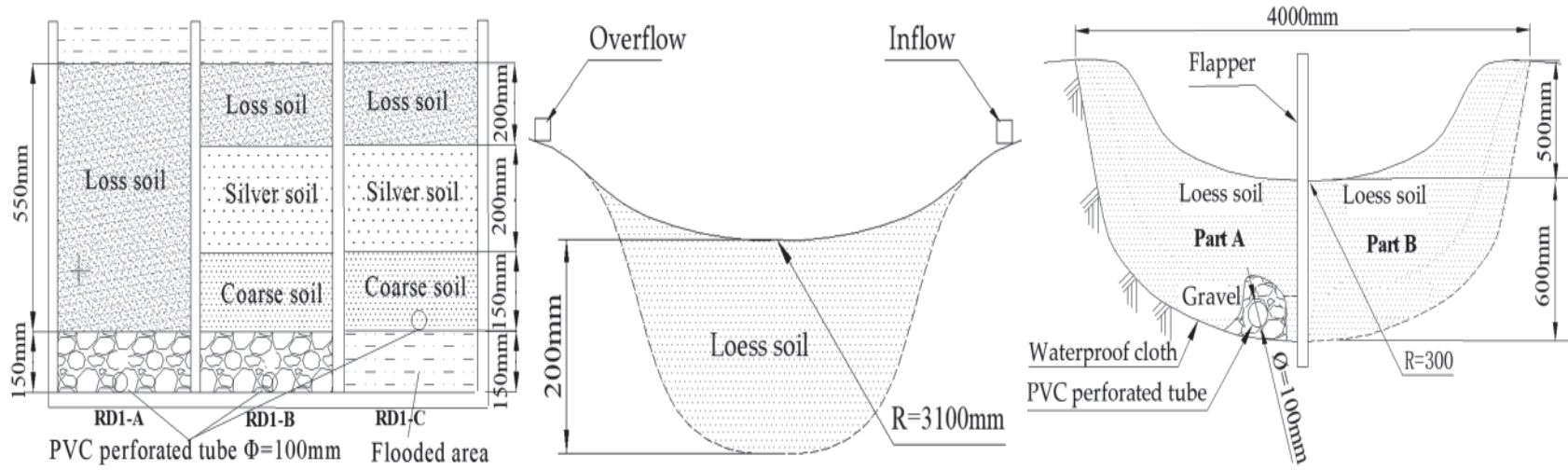

Fig. 2. The structure of three rain gardens. 
RG3-E (a comparison soil sample (CS) was taken $3 \mathrm{~m}$ far from RG2) on $27^{\text {th }}$ April, $7^{\text {th }}$ July and $14^{\text {th }}$ October 2018. The fresh sediment samples are collected by plastic shovel, and one sample is about $1 \mathrm{~kg}$. The fresh soil samples were collected about $500 \mathrm{~g}$ at three points (on the concentric circle in RG1 and on the straight line in RG3-E), then mixed the three samples thoroughly to be used as a test sample. The soil profile of RG2was deep, so samples in five layers were collected, and they were $0 \sim 10 \mathrm{~cm}, 20 \sim 30 \mathrm{~cm}, 40 \sim 50 \mathrm{~cm}, 70 \sim 80 \mathrm{~cm}$, $90 \sim 100 \mathrm{~cm}$, respectively. Soil profile of RG3-Ewas shallow $(60 \mathrm{~cm})$, so it was divided into three layers from 0 to $10 \mathrm{~cm}, 20$ to $30 \mathrm{~cm}$, and 40 to $50 \mathrm{~cm}$, respectively. And CS was collected at $0 \sim 10 \mathrm{~cm}, 20 \sim 30 \mathrm{~cm}$, $40 \sim 50 \mathrm{~cm}, 70 \sim 80 \mathrm{~cm}$.

\section{Soil Analysis}

All samples were naturally ventilated and dried. The grass roots and other impurities were removed. A part of the samples dried previously was passed through a 200-mesh sieve to measure $\mathrm{NH}_{3}-\mathrm{N}$ and $\mathrm{NO}_{3}-\mathrm{N}$ content, and another part was passed through a 100mesh sieve to measure TN, TP, Cu, Zn, Cd and enzyme, and the other passed through a 60 -mesh sieve to measure TOC. The sub-samples were all stored in a refrigerator at $-20^{\circ} \mathrm{C}$ after the previous treatment, and all indicators were completed within 1 week.

The soil TOC was determined by potassium dichromate oxidation-spectrophotometry. The standard curve was drawn with $10 \mathrm{~g} \mathrm{~L}^{-1}$ glucose standard solution. $0.1 \mathrm{~g}$ of mercury sulfate, $5.00 \mathrm{ml}$ of potassium dichromate solution and $7.5 \mathrm{ml}$ of sulfuric acid were added to the soil samples. The mixture was heated in a thermostat heater at $135^{\circ} \mathrm{C}$ for $30 \mathrm{~min}$. The supernatant was taken after cooling, and centrifuged at $2000 \mathrm{r} / \mathrm{min}$ for $10 \mathrm{~min}$, and finally the absorbance was measured at $585 \mathrm{~nm}$.

Soil $\mathrm{NH}_{3}-\mathrm{N}$ was extracted by the potassium chloride solution from the soil. Under alkaline conditions, the ammonia ion in the extract reacted with phenol in the presence of hypochlorite ions, and it formed a blue indophenol solution, then the absorbance was measured at $630 \mathrm{~nm}$ [24]. Soil $\mathrm{NO}_{3}-\mathrm{N}$ and $\mathrm{NO}_{2}-\mathrm{N}$ was extracted by the potassium chloride solution from the soil, and the extract passed through a reduction column to reduce nitrate nitrogen to nitrite nitrogen. Under acidic conditions, nitrite nitrogen reacted with sulfonamide to form diazonium salt. Then, it was coupled with $\mathrm{N}$-(1-naphthyl)-ethylenediamine hydrochloride to form a red solution with the maximum absorption at a wavelength of $543 \mathrm{~nm}$. The total amount of nitrate nitrogen and nitrite nitrogen were determined and the difference between the total amount of nitrate nitrogen and nitrite nitrogen was the nitrate nitrogen content [24]. Dual beam UV-visible spectrophotometer (UV-2100) was used for the measurement of soil $\mathrm{NH}_{3}-\mathrm{N}$ and $\mathrm{NO}_{3}-\mathrm{N}$. The concentration of $\mathrm{TN}$ in the soil was determined by alkaline potassium persulfate digestion
[25] and analyzed by the UV spectrophotometric method [26]. To measure the concentrations of TP, the soil was first heated at $450^{\circ} \mathrm{C}$ for $3 \mathrm{~h}$, extracted by $20 \mathrm{~mL}$ of $3.5 \mathrm{M} \mathrm{HCl}$ for $16 \mathrm{~h}$, and then determined using the ascorbic acid method [26]. The contents of $\mathrm{TN} / \mathrm{TP}$ in the soil were expressed as $\mathrm{mg} \mathrm{TN} / \mathrm{TP} \mathrm{g}^{-1}$.

Soil $\mathrm{Cu}, \mathrm{Zn}$ and $\mathrm{Cr}$ were determined by flame atomic absorption spectrophotometry, and $\mathrm{Pb}$ and $\mathrm{Cd}$ were determined by graphite furnace atomic absorption spectrophotometry. The methods use a total decomposition of hydrochloric acid, nitric acid, hydrofluoric acid, and perchloric acid to completely destroy the mineral crystal lattice of the soil, so that all the elements to be measured in the sample enter the sample.

The activity of soil urease was determined by starch blue colorimetry, and the absorbance was measured at $578 \mathrm{~nm}$. The soil urease activity was expressed in milligrams as $\mu \mathrm{g} \mathrm{NH}_{3}-\mathrm{N} \mathrm{g}^{-1}$. The sucrase was determined by 3, 5-diyl salicylic acid colorimetry, and the absorbance was determined at $508 \mathrm{~nm}$. The sucrase activity was expressed as $\mu \mathrm{g}$ glucose $\mathrm{g}^{-1}$. The protease was measured by Ninhydrin colorimetry, and the absorbance was measured at $560 \mathrm{~nm}$. The activity of the soil protease was expressed as $\mu \mathrm{g} \mathrm{C}_{2} \mathrm{H}_{3} \mathrm{NO}_{2} \mathrm{~g}^{-1}$. Soil phosphatase activity was measured by phenyl phosphate sodium colorimetry, and the absorbance was measured at $660 \mathrm{~nm}$. The phosphatase activity was expressed as $\mu \mathrm{g} \mathrm{P}_{2} \mathrm{O}_{5} \mathrm{~g}^{-1}$. Dual beam UV-visible spectrophotometer (UV-2100) was used for the measurement of enzyme activity.

Sigma Plot12.5 (developed by Systat software company, USA; the supplier is Beijing ND Times Technology Co., Ltd. BeiJing, China), Minitab (developed by Pennsylvania State University, Commonwealth of Pennsylvania, USA) and SPSS 20.0 (developed by Stanford University, California, USA) were used for data analysis.

\section{Results and Discussion}

\section{Water Quality of the Inflow}

Forty-two rainfall events about rain garden of RG1 were monitored during the period from March 2011 to August 2018. The runoff volume reduction ranged from $9.80 \%$ to $100.0 \%$, and the flood peak flow reduction rate varied from $20.3 \%$ to $100.0 \%$.The $\mathrm{NH}_{3}-\mathrm{N}, \mathrm{NO}_{3}-\mathrm{N}, \mathrm{TN}$, $\mathrm{TP}$ and TSS concentration reduction rate varied from $7.83 \% \sim 94.22 \%, \quad-583.50 \% \sim 58.65 \%, \quad-119.30 \% \sim 85.06 \%$, $-467.40 \% \sim 48.89 \%,-18.60 \% \sim 100.0 \%$ [6]. A total of 47 rainfall events were monitored of RG2, and only eight rainfall events produced the overflow from the system. The annual average runoff volume reduction rate of RG2 was more than $97.3 \%$ [6]. Because of the special structure of RG3 with $0.5 \mathrm{~m}$ aquifer, no overflow occurred in case of RG3-E from 2012 to now. The runoff volume reduction rate of RG3-E was $100.0 \%$, so 
Table 2. EMC and the pollutants load of inflow (2016 2019).

\begin{tabular}{|c|c|c|c|c|c|c|}
\hline \multirow{2}{*}{ Items } & \multicolumn{2}{|c|}{ RG1 } & \multicolumn{2}{|c|}{ RG2 } & \multicolumn{2}{|c|}{ RG3 } \\
\hline & $\mathrm{EMC} /(\mathrm{mg} / \mathrm{L})$ & Load $/\left(\mathrm{g} / \mathrm{m}^{2}\right)$ & $\mathrm{EMC} /(\mathrm{mg} / \mathrm{L})$ & Load $/\left(\mathrm{g} / \mathrm{m}^{2}\right)$ & $\mathrm{EMC} /(\mathrm{mg} / \mathrm{L})$ & Load $/\left(\mathrm{g} / \mathrm{m}^{2}\right)$ \\
\hline COD & 68.15 & 237.27 & 103.91 & 1205.62 & 57.78 & 502.85 \\
\hline TSS & 49.79 & 173.33 & 93.55 & 1085.37 & 65.04 & 566.04 \\
\hline $\mathrm{NH}_{3}-\mathrm{N}$ & 1.03 & 3.59 & 2.45 & 28.37 & 1.14 & 9.92 \\
\hline $\mathrm{NO}_{3}-\mathrm{N}$ & 1.05 & 3.67 & 1.11 & 12.91 & 1.57 & 13.69 \\
\hline TN & 3.06 & 10.66 & 4.24 & 49.16 & 3.09 & 26.91 \\
\hline TP & 0.21 & 0.74 & 0.32 & 3.76 & 0.23 & 1.99 \\
\hline $\mathrm{Cu}$ & - & - & 0.044 & 0.662 & 0.106 & 1.201 \\
\hline $\mathrm{Zn}$ & - & - & 0.281 & 4.212 & 0.630 & 7.102 \\
\hline $\mathrm{Cd}$ & - & - & 0.022 & 0.032 & 0.031 & 0.035 \\
\hline
\end{tabular}

all the pollutants carried in the rainfall runoff entered the system [6]. The pollutant EMC concentration and the load of inflow were shown in Table 2. The $\mathrm{N}$ and $\mathrm{P}$ concentration of roof runoff are all less than that of road runoff, and the heavy metals mainly come from road runoff. Therefore, pollutants carried by rainfall runoff is one of the important sources of pollution in rain gardens.
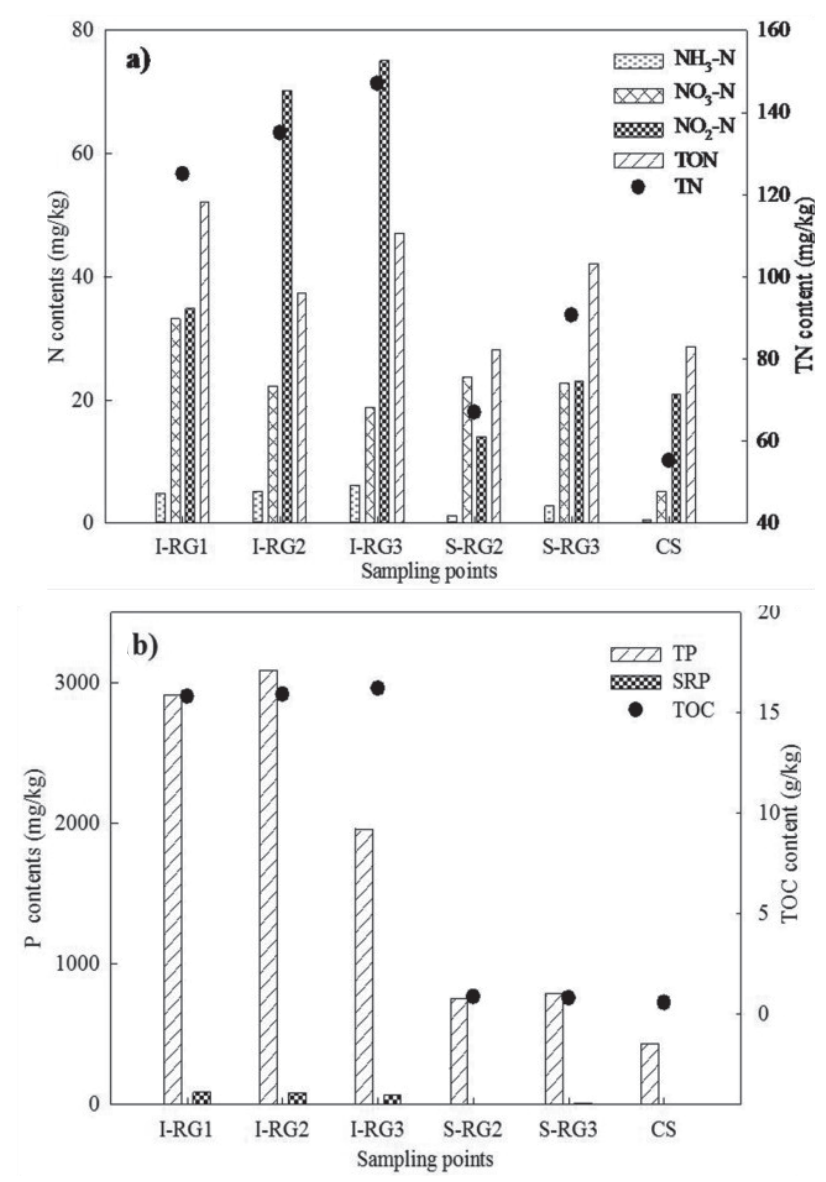

Fig. 3. N, P and TOC in sediment and soil.

\section{$\mathrm{N}$ and $\mathrm{P}$ in Sediment and Soil of Rain Garden}

The content of N, P and TOC in sediment of three inflow weirs (abbreviated asI-RG1, I-RG2 and I-RG3) and two rain garden soil (abbreviated asS-RG2 and $\mathrm{S}-\mathrm{RG} 3$ ), are shown in Fig. 3a). It can be seen that $\mathrm{NO}_{2}-\mathrm{N}$ and TON are the main forms in the inflow weir sediments, but the situation is different for the soil $\mathrm{N}, \mathrm{NO}_{3}-\mathrm{N}$ and TON are the main forms. However, the content of $\mathrm{NH}_{3}-\mathrm{N}$ in the sediment and soil of the rain garden is less, and the other forms of $\mathrm{N}$ are all greater than those of $\mathrm{NH}_{3}-\mathrm{N}$. The $\mathrm{N}$ content in $\mathrm{CS}$ is the least.

The order of $\mathrm{N}$ content in the I-RG1 is $\mathrm{NH}_{3}-\mathrm{N}<$ $\mathrm{NO}_{3}-\mathrm{N}<\mathrm{NO}_{2}-\mathrm{N}<\mathrm{TON}<\mathrm{TN}$, but they are in order of $\mathrm{NH}_{3}-\mathrm{N}<\mathrm{NO}_{3}-\mathrm{N}<\mathrm{TON}<\mathrm{NO}_{2}-\mathrm{N}<\mathrm{TN}$ in I-RG2 and I-RG3. $\mathrm{NO}_{2}-\mathrm{N}$ in the I-RG2 and I-RG3 is significantly greater than that in I-RG1. This is mainly due to the structure of the weir of rain garden of RG2 and RG3. A certain amount of rainwater is still stored in the inflow weir after the rainfall, and the sediment in the weir is in an anoxic state, thus the presence of a saturated zone for nitrate denitrification provides good conditions, which convert nitrate to nitrite $[14,23]$. The inflow weir of RG1 is a horizontal PVC pipe. The water in the PVC pipe is gradually evaporated after the rainfall, and the sediment is in an aerobic state in the inflow weir, so the nitrite content is less. However, The $\mathrm{N}$ in the sediment of the rain garden mainly comes from the scouring of the rainfall on the underlying surface of the catchment area. Research shows that due to the vehicle exhaust, tire wear and pedestrian that results the road runoff has great concentration of $\mathrm{N}$ [13]. This study proved the conclusion, and $\mathrm{TN}$ in I-RG3 is the greatest.

It is found that the contents of $\mathrm{NH}_{3}-\mathrm{N}, \mathrm{NO}_{3}-\mathrm{N}$, $\mathrm{NO}_{2}-\mathrm{N}, \mathrm{TON}$ and $\mathrm{TN}$ in the I-RG2 are 5.12, 22.25, $70.21,37.42$ and $135.0 \mathrm{mg} / \mathrm{kg}$, respectively, but they are $1.13,23.73,14.04,28.10$ and $67.0 \mathrm{mg} / \mathrm{kg}$ in the S-RG2. It can be seen that the contents of $\mathrm{NH}_{3}-\mathrm{N}, \mathrm{NO}_{3}-\mathrm{N}, \mathrm{NO}_{2}-\mathrm{N}$, TON and TN in the I-RG2 are 4.54, 0.94, 5.0, 2.01, and 
1.33 times greater than those in the S-RG2. However the situation is same as the RG3, and the contents of $\mathrm{NH}_{3}-\mathrm{N}, \mathrm{NO}_{3}-\mathrm{N}, \mathrm{NO}_{2}-\mathrm{N}, \mathrm{TON}$ and $\mathrm{TN}$ in the I-RG3 are $2.21,0.83,3.25,1.62$ and 1.11 times greater than that in the S-RG3. N contents in the I-RG2 and I-RG3 are all greater than those of soil $\mathrm{N}$, except for $\mathrm{NO}_{3}-\mathrm{N}$. Of course, the various forms of $\mathrm{N}$ in $\mathrm{CS}$ is the least. According to Hatt [4] the experimental results showed that the sedimentary TP, OM, and TN levels of the entire Nansi Lake appeared to be higher in the upstream lake than in the downstream lake. Therefore, setting up the sedimentation tank has a better effect on pollutants interception carried by rainfall runoff. However, less $\mathrm{NO}_{3}-\mathrm{N}$ content is observed in the sediment. This is mainly due to the long time anaerobic conditions in the sediment that make the content of $\mathrm{NO}_{3}-\mathrm{N}$ converse to $\mathrm{NO}_{2}-\mathrm{N}$.

The soluble reactive phosphorus (SRP) is small in the sediment and soil of rain garden, and most of the $\mathrm{P}$ in the sediment is in the form of particles. It can be seen from Fig. 3b) that the content of $P$ in the sediment of the inflow weirs is much greater than those of soil P, however, CS has small contents of P. TP and SRP in I-RG2 are 3084.0 and $85.62 \mathrm{mg} / \mathrm{kg}$, respectively, but they are 751.2 and $5.97 \mathrm{mg} / \mathrm{kg}$ in S-RG2. And TP and SRP in sediment are 4.1 and 14.3 times greater than those in soil. TP and SRP are 1959.0 and $65.68 \mathrm{mg} / \mathrm{kg}$ in I-RG3, but 791.0 and $12.29 \mathrm{mg} / \mathrm{kg}$ in S-RG3. And they are 2.5 and 5.3 times greater in I-RG3 than those in $\mathrm{S}-\mathrm{RG} 3$. Therefore, $\mathrm{P}$ is well precipitated in the inflow weirs. Study shows that particulate $P$ is mostly adsorbed on the deposits of underling, and it is deposited greatly with the migration of rainfall runoff [27]. Therefore, more TP content is observed in the sediment.

The order of TOC content in the sediment of the three inflow weirs are I-RG1 $<\mathrm{I}-\mathrm{RG} 2<\mathrm{I}-\mathrm{RG} 3$. This showed that a large amount of TOC is from road runoff, while it is less in the roof runoff. It is mainly because the road surface generates a lot of organic pollutants due to tire wear, vehicle exhaust and pedestrian [28]. During the rainfall scouring, the organic pollutants carried in the road deposit enter the inflow weirs with the runoff. And the TOC content in the sediment are all greater than those in rain garden soil.

To sum up, the sediment in the inflow weirs contains great amount of N, P and TOC, therefore, pollutants in rainfall runoff are effectively precipitated by inflow weirs. And this could reduce the pollutants volume entered the rain garden. Thus, if rain garden is used for regulating stomwater runoff, sedimentation tank for intercepting pollutants is necessary. It can effectively reduce the concentration of pollutants entering the rain garden, and relieve the soil pollution level in rain gardens.

\section{Heavy Metals in Sediment and Soil of Rain Garden}

The order of heavy metal contents in the sediment is $\mathrm{Zn}>\mathrm{Cu}>\mathrm{Cd}$, which indicates that the $\mathrm{Zn}$ content is

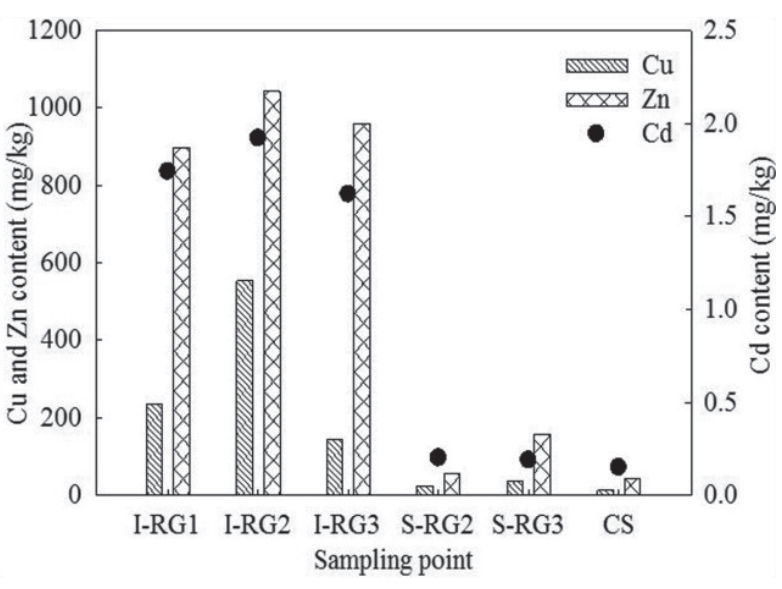

Fig. 4. Heavy metals in sediment and soil.

great in rainfall runoff. The contents of $\mathrm{Cu}, \mathrm{Zn}$ and $\mathrm{Cd}$ in three inflow weirs are I-RG2>I-RG3>I-RG1. This is mainly due to the landfill plant on the east side of RG2, and when the campus garbage is cleaned and transported every day, the dust will fall on the underlying surface. The result is attributed to the fact that heavy metals tend to attach to the suspended solids in stormwater [29], and they easily enter the inflow weirs with the rainfall runoff. Relevant research shows surface sediments from a seaport, aquaculture facilities, wastewater discharges, Huanghe (Yellow) River estuary and wetland has great contents of $\mathrm{Cu}, \mathrm{Pb}, \mathrm{Zn}, \mathrm{Cr}, \mathrm{Ni}$, Cd [21].

From Fig. 4, it can be seen that the heavy metal contents in the sediment are much greater than those in soil. The contents of $\mathrm{Cu}$ in the I-RG1, I-RG2 and I-RG3 are 235.93, 553.17, $143.03 \mathrm{mg} / \mathrm{kg}$, respectively, but they are 24.62 and $35.57 \mathrm{mg} / \mathrm{kg}$ in the S-RG2 and $\mathrm{S}-\mathrm{RG} 3$. The contents of $\mathrm{Cu}$ in the I-RG2 and I-RG3 are 22.47 and 4.02 times greater than those in the S-RG2 and S-RG3. The average contents of $\mathrm{Zn}$ in the I-RG1, I-RG2 and I-RG3 are 897.49, 1043.02, $959.65 \mathrm{mg} / \mathrm{kg}$, respectively, however, they are 55.11 and $157.14 \mathrm{mg} / \mathrm{kg}$ in the S-RG2 and S-RG3. The contents of $\mathrm{Zn}$ in the I-RG2 and I-RG3 are 18.93 and 6.11 times greater than that in the S-RG2 and S-RG3. The contents of $\mathrm{Zn}$ are $1.742,1.921,1.620 \mathrm{mg} / \mathrm{kg}$ in the I-RG1, I-RG2 and I-RG3, but they are 0.202 and $0.189 \mathrm{mg} / \mathrm{kg}$ in the S-RG2 and S-RG3, respectively. The contents of $\mathrm{Zn}$ in the I-RG2 and I-RG3 are 4.60 and 8.57 times greater than that in the S-RG2 and S-RG3. A large amount of heavy metals accumulated in sediment of the inflow weirs, which greatly reduced the soil heavy metal contents in the rain gardens. $\mathrm{Hu}$ [30] studied the distribution characteristics and contamination assessment of heavy metals in surface sediments of Chaohu Lake, China, He declared that the heavy metal distribution of surface sediment indicated a higher degree of contamination in the east and west regions of the lake than that in the middle region. Other research shows that most of the heavy metals in rainfall runoff are attached to the underlying deposit. When rainfall scouring, they enter 


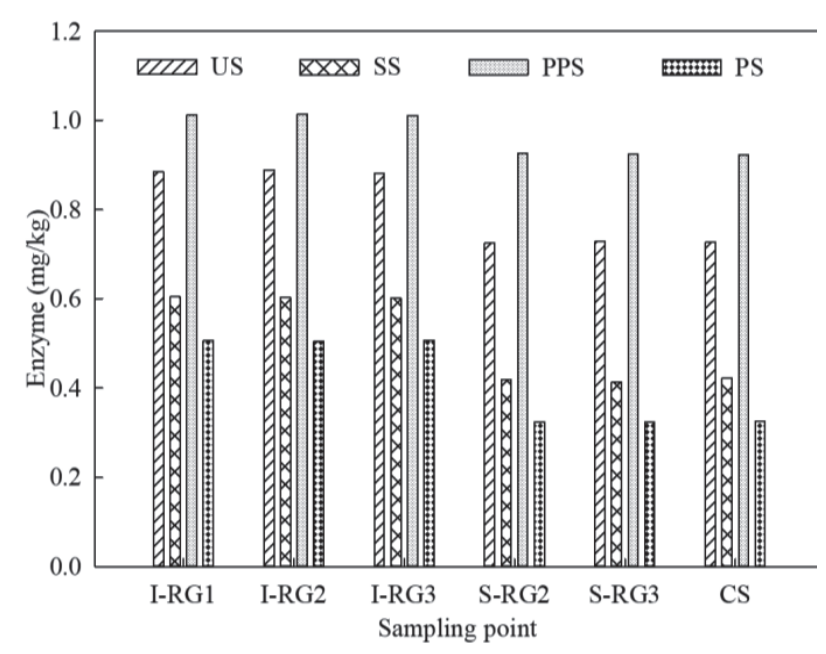

Fig. 5. Enzyme activity in sediment and soil.

the LID facilities with runoff [31]. The other research was found that $13.11 \%$ particles can be washed-off from the road surfaces, and a vast majority (12.40\%) of suspended solids (SS) in the road surface runoff was retained by LID. Thus LID practices can significantly reduce the contribution of road deposited sediments pollution to urban receiving water [32]. Therefore, sedimentation tank should be set up before runoff entering the LID facility, which can effectively reduce the pollutants volume.

\section{Enzyme Activity in Sediment and Soil of Rain Garden}

The enzyme activities (Fig. 5) in the sediment and soil of the three rain gardens are phosphatase (PPS)> urease $(\mathrm{SU})>$ sucrase $(\mathrm{SS})>$ protease $(\mathrm{PS})$. And they are slightly greater in the sediment than those in soil. Although the rain garden inflow weirs of RG1 and RG2 are cleaned less frequently, and the sediment retention time in weirs are long. While the inflow weir of RG3 is thoroughly cleaned in March 2018 and the sediment retention time is short, however, the difference of enzyme activity in the sediment of three inflow weirs is very small. This result indicates that the pollutants carried by the stomwater runoff are not enough to have a greater impact on the enzyme activity, and the moist environment is more conducive to the growth of enzymes [33]. On the other hand, rainfall runoff contains a lot of nutrients, which promotes the growth of enzyme activity [34]. It further confirmed

Table 3. Multiple linear regression analysis.

\begin{tabular}{|c|c|c|c|c|c|c|c|c|}
\hline Index & Parameter & Coefficient & Std. Error & $t$ value & $P$ value & VIF & $\mathrm{R}^{2}$ & $\mathrm{R}^{2}(\operatorname{Adj})$ \\
\hline \multirow{5}{*}{$\mathrm{NH}_{3}-\mathrm{N}$} & Constant & -1.5 & 107.3 & -0.014 & 0.989 & - & - & - \\
\hline & SU & 233.2 & 88.2 & 2.642 & 0.033 & 399.8 & - & - \\
\hline & SS & -130.0 & 85.1 & -1.529 & 0.170 & 509.4 & - & - \\
\hline & PPS & -120.9 & 156.5 & -0.773 & 0.465 & 380.9 & - & - \\
\hline & Equation & \multicolumn{5}{|c|}{$\mathrm{NH}_{3}-\mathrm{N}=-1.5+(233.2 * \mathrm{SU})-(130.0 * \mathrm{SS})-(120.9 * \mathrm{PPS})$} & 0.71 & 0.59 \\
\hline \multirow{5}{*}{$\mathrm{NO}_{3}-\mathrm{N}$} & Constant & -192.5 & 940.0 & -0.205 & 0.884 & - & - & - \\
\hline & SU & 2331.5 & 772.9 & 3.016 & 0.019 & 399.8 & - & - \\
\hline & SS & -1474.9 & 745.0 & -1980 & 0.088 & 509.4 & - & - \\
\hline & PPS & -943.8 & 1371.1 & -0.688 & 0.513 & 380.9 & - & - \\
\hline & Equation & \multicolumn{5}{|c|}{$\mathrm{NO}_{3}-\mathrm{N}=-192.5+(2331.5 * \mathrm{SU})-(1474.9 * \mathrm{SS})-(943.8 * \mathrm{PPS})$} & 0.66 & 0.52 \\
\hline \multirow{5}{*}{$\mathrm{NO}_{2}-\mathrm{N}$} & Constant & -1229.0 & 1064.4 & -1.155 & 0.286 & - & - & - \\
\hline & SU & 1247.0 & 875.3 & 1.425 & 0.197 & 399.8 & - & - \\
\hline & SS & -1327.5 & 843.6 & -1.574 & 0.160 & 509.4 & - & - \\
\hline & PPS & 966.9 & 1552.6 & 0.623 & 0.553 & 380.9 & - & - \\
\hline & Equation & \multicolumn{5}{|c|}{$\mathrm{NO}_{2}-\mathrm{N}=-1229.0+(1247.0 * \mathrm{SU})-(1327.7 * \mathrm{SS})+(966.9 * \mathrm{PPS})$} & 0.81 & 0.72 \\
\hline \multirow{5}{*}{ TON } & Constant & 157.4 & 342.4 & 0.460 & 0.660 & - & - & - \\
\hline & SU & 46.3 & 281.6 & 0.164 & 0.874 & 399.8 & - & - \\
\hline & SS & 60.4 & 271.4 & 0.223 & 0.830 & 509.4 & - & - \\
\hline & PPS & -184.6 & 499.5 & -0.370 & 0.723 & 380.9 & - & - \\
\hline & Equation & \multicolumn{5}{|c|}{$\mathrm{TON}=157.4+(46.3 * \mathrm{SU})+(60.4 * \mathrm{SS})-(184.6 * \mathrm{PPS})$} & 0.16 & 0.0 \\
\hline
\end{tabular}


Table 3. Continued

\begin{tabular}{|c|c|c|c|c|c|c|c|c|}
\hline \multirow{5}{*}{$\mathrm{TN}$} & Constant & -1265.6 & 1408.2 & -0.899 & 0.399 & - & - & - \\
\hline & SU & 3857.9 & 1157.9 & 3.332 & 0.013 & 399.8 & - & - \\
\hline & $\mathrm{SS}$ & -2872.1 & 1116.1 & -2.573 & 0.037 & 509.4 & - & - \\
\hline & PPS & -282.3 & 2053.9 & -0.137 & 0.895 & 380.9 & - & - \\
\hline & Equation & \multicolumn{5}{|c|}{$\mathrm{TN}=-1265.6+(3857.9 * \mathrm{SU})-(2872.1 * \mathrm{SS})-(282.3 * \mathrm{PPS})$} & 0.87 & 0.81 \\
\hline \multirow{5}{*}{ SRP } & Constant & 362.4 & 921.9 & 0.393 & 0.706 & - & - & - \\
\hline & SU & 1092.8 & 758.1 & 1.441 & 0.193 & 399.8 & - & - \\
\hline & $\mathrm{SS}$ & 42.6 & 730.7 & 0.058 & 0.955 & 509.4 & - & - \\
\hline & PPS & -1259.9 & 1344.7 & -0.937 & 0.380 & 380.9 & - & - \\
\hline & Equation & \multicolumn{5}{|c|}{$\mathrm{SRP}=362.4+(1092.8 * \mathrm{SU})+(42.6 * \mathrm{SS})-(1259.9 * \mathrm{PPS})$} & 0.95 & 0.93 \\
\hline \multirow{5}{*}{ TP } & Constant & -20953.8 & 54068.8 & -0.388 & 0.712 & - & - & - \\
\hline & SU & 27947.1 & 31240.6 & 0.895 & 0.405 & 410.3 & - & - \\
\hline & SS & -18352.6 & 42469.8 & -0.432 & 0.681 & 1030.5 & - & - \\
\hline & PPS & 9824.6 & 73824.1 & 0.133 & 0.898 & 698.5 & - & - \\
\hline & Equation & \multicolumn{5}{|c|}{$\mathrm{TP}=-20953.8+(27947.1 * \mathrm{SU})-(18352.6 * \mathrm{SS})+(9824.6 * \mathrm{PPS})$} & 0.91 & 0.97 \\
\hline \multirow{5}{*}{ TOC } & Constant & -73.8 & 34.3 & -2.155 & 0.068 & - & - & - \\
\hline & SU & 15.2 & 28.2 & 0.538 & 0.607 & 399.8 & - & - \\
\hline & SS & 45.6 & 27.2 & 1.681 & 0.137 & 509.4 & - & - \\
\hline & PPS & 48.3 & 50.0 & 0.965 & 0.366 & 380.9 & - & - \\
\hline & Equation & \multicolumn{5}{|c|}{$\mathrm{TOC}=-73.8+(15.2 * \mathrm{SU})+(45.6 * \mathrm{SS})+(48.3 * \mathrm{PPS})$} & 0.99 & 0.98 \\
\hline \multirow{5}{*}{$\mathrm{Cu}$} & Constant & -8901.8 & 10433.9 & -0.853 & 0.422 & - & - & - \\
\hline & SU & 10063.2 & 8579.9 & 1.173 & 0.279 & 399.8 & - & - \\
\hline & SS & -10000.1 & 8269.5 & -1.209 & 0.266 & 509.4 & - & - \\
\hline & PPS & 6261.1 & 15218.7 & 0.411 & 0.693 & 380.9 & - & - \\
\hline & Equation & $\mathrm{Cu}=-8901.8$ & $63.2 * \mathrm{SU})$ & $10000.1^{*}$ & ) $+(6261$. & PPS) & 0.73 & 0.62 \\
\hline & Constant & -6641.9 & 4583.6 & -1.449 & 0.191 & - & - & - \\
\hline & SU & 14002.2 & 3769.2 & 3.715 & 0.008 & 399.8 & - & - \\
\hline $\mathrm{Zn}$ & SS & -6989.8 & 3632.8 & -1.924 & 0.096 & 509.4 & - & - \\
\hline & PPS & -561.2 & 6685.5 & -0.084 & 0.935 & 380.9 & - & - \\
\hline & Equation & $\mathrm{Zn}=-6641$ & $002.2 * \mathrm{SL}$ & (6989.8 & S) - $(561.2$ & PS) & 0.99 & 0.98 \\
\hline & Constant & -7.33 & 9.58 & -0. & 0.47 & - & - & - \\
\hline & $\mathrm{SU}$ & 11.76 & 7.88 & 1.4 & 0.18 & 399.8 & - & - \\
\hline $\mathrm{Cd}$ & SS & -1.41 & 7.60 & -0 . & 0.86 & 509.4 & - & - \\
\hline & PPS & 0.46 & 13.98 & -0. & 0.98 & 380.9 & - & - \\
\hline & Equation & $\mathrm{Cd}=-$ & $11.76 * \mathrm{SU}$ & $(1.41 * \mathrm{~S}$ & $-\left(0.46^{*} \mathrm{PP}\right.$ & & 0.99 & 0.98 \\
\hline
\end{tabular}

Note: There are independent variables in the regression model that appear to be highly correlated with other independent variables or have no variability. These variables have been removed from the regression model. The specific variables are: removed protease, because it is collinear.

the fact that the enzyme activity in the soil is mainly affected by the external environment, such as the physical and chemical properties of the environment
( $\mathrm{pH}$, temperature, humidity, etc.), fertilization status, grazing, soil microorganisms and different land use, etc [35]. 
The Relation of Pollutants and Enzyme Activity

The multivariate linear regression found that the $\mathrm{N}, \mathrm{P}, \mathrm{TOC}$ and heavy metals content in sediment and soil have a good linear relationship with the activity of enzymes, and the $\mathrm{R}^{2}$ are all more than 0.66 , except for TON (Table 3). Especially, the linear relationships of the $\mathrm{Cu}, \mathrm{Zn}$ and TOC with enzymes activity are very good, and the $\mathrm{R}^{2}$ reached 0.99 . In addition, the relationships of $\mathrm{P}$ with enzymes activity are also good, and the $\mathrm{R}^{2}$ are more than 0.91 . However, the relationships of $\mathrm{N}$ with enzymes activity are unstable. This is mainly due to the variability of $\mathrm{N}$ in the soil [36]. All pollutants are positively correlated with SU, but most of them are negatively correlated with SS. However, a part of the pollutants is positively correlated PPS, and the others are opposite. SU can convert amide organic $\mathrm{N}$ into plantavailable inorganic $\mathrm{N}$ [37]. Therefore, US can promote the accumulation of soil inorganic N. In this study, the inorganic $\mathrm{N}$ content in the sediment is great, but TON is the same as the content in soil. So greatly increased the organic $\mathrm{N}$ decomposition in sediment. PPS can promote the mineralization and resolution of organic phosphorus in the soil, and improve the absorption and utilization efficiency of plants [38].

\section{Conclusions}

In this study, the pollutants variations in sediment of inflow weir and loess soil of rain gardens are explored at the field scale. The main conclusions are presented as follows:

(1) $\mathrm{NO}_{2}-\mathrm{N}$ and $\mathrm{TON}$ are the main forms of $\mathrm{N}$ in the inflow weir sediments of the rain garden, but the situation is different for the soil $\mathrm{N}$, and $\mathrm{NO}_{3}-\mathrm{N}$ and TON are the main forms in soil. The sediment in the inflow weirs contains great amount of $\mathrm{N}, \mathrm{P}$ and TOC, except for $\mathrm{NO}_{3}-\mathrm{N} . \mathrm{NH}_{3}-\mathrm{N}, \mathrm{NO}_{3}-\mathrm{N}, \mathrm{NO}_{2}-\mathrm{N}, \mathrm{TON}$ and $\mathrm{TN}$ in the I-RG2 are 4.54, 0.94, 5.0, 2.01, and 1.33 times greater than those in the S-RG2, and they are 2.21, 0.83, 3.25, 1.62 and 1.11 times greater in I-RG3 than those in the S-RG3.

(2) The soluble reactive phosphorus (SRP) is small in the sediment of the three inflow weirs. The content of $\mathrm{P}$ in the sediment of the weirs is much greater than those in the soil. TP and SRP in I-RG2 are 4.1 and 14.3 times greater than those in soil, and they are 2.5 and 5.3 times greater in I-RG3 than those in S-RG3.

(3) The heavy metal contents of $\mathrm{Cu}, \mathrm{Zn}$ and $\mathrm{Cd}$ in sediment are much greater. $\mathrm{Cu}$ is 22.47 and 4.02 times greater in sediment than that in soil, and they are $18.93,6.11$ and 4.60, 8.57 times for $\mathrm{Zn}$ and $\mathrm{Cd}$. Therefore pollutants in rainfall runoff are effectively precipitated by weirs, and it can reduce the concentration of pollutants entering the rain garden, thus relieve the soil pollution level in rain garden.
(4) The enzyme activities in the sediment are slightly greater than those in soil. The N, P, TOC and heavy metals contents have a good linear relationship with the activity of enzymes, and the $\mathrm{R}^{2}$ are all more than 0.66 .

\section{Acknowledgments}

This research was financially supported by the Natural Science Foundation of Shaanxi Province (2020SF-420), the project of Shaanxi Provence Land Engineering Construction Group (DJNY2020-27) and the National Natural Science Foundation of China (No. 51879215).

\section{Conflict of Interest}

The authors declare no conflict of interest.

\section{Reference}

1. GUO C., LI J.K., LI H.E., LI Y.J. Influences of stormwater concentration infiltration on soil nitrogen, phosphorus, TOC and their relations with enzyme activity in rain garden. Chemosphere. 233, 207, 2019.

2. BACH P.M., MCCARTHY D.T., DELETIC A. Redefining the stormwater first flush phenomenon. Water Res. 44, 2487, 2010.

3. WANG J., ZHANG P., YANG L., HUANG T. Cadmium removal from urban stormwater runoff via bioretention technology and effluent risk assessment for discharge to surface water. J. Contam Hydrol. 185-186, 42, 2016.

4. VIRAHSAWMY H.K., STEWARDSON M.J., VIETZ G., FLETCHER T.D. Factors that affect the hydraulic performance of raingardens: implications for design and maintenance. Water Sci.Technol. 69 (5), 982, 2014.

5. BLECKEN G.T., ZINGER Y., DELETIC A., FLETCHER T.D., HEDSTROM A., VIKLANDER M. Laboratory study on stormwater biofiltration nutrient and sediment removal in cold temperatures. J. Hydrol. 394 (3-4), 507, 2010.

6. GUO C., LI J.K., LI H.E., ZHANG B., MA M.H., LI F. Seven-Year Running Effect Evaluation and Fate Analysis of Rain Gardens in Xi'an, Northwest China. Water. 10, 944, 2018.

7. LIU J.Y., DAVIS A.P. Phosphorus speciation and treatment using enhanced phosphorus removal bioretention.Environ. Sci. Technol. 48, 607, 2014.

8. BROWN R.A., LINE D.E., HUNT W.F. LID treatment train: Pervious concrete with subsurface storage in series with bioretention and care with seasonal high water tables. J. Environ. Eng. 138, 689,2012.

9. SUN Y., SUN G., XU Y.M., WANG L., LIANG X.F., LIN D.S., HU F.Z. Assessment of natural sepiolite on cadmium stabilization, microbial communities, and enzyme activities in acidic soil.Environ Sci. Pollut R. 20, 3290, 2013

10. MAHAJANG R., MANJUNATHB L., LATARE A.M., VISHWAKARMA S., SINGHN. P. Microbial and Enzyme Activities and Carbon Stock in Unique Coastal Acid Saline Soils of Goa. Proceedings of the National Academy 
of Sciences, India Section B: Biological Sciences, 86, 961,2016.

11. TANG S., LUO W., JIA Z., LIU W., LI S., WU Y.Evaluating Retention Capacity of Infiltration Rain Gardens and Their Potential Effect on Urban Stormwater Management in the Sub-Humid Loess Region of China, Water Resour Manag. 30, 983, 2016.

12. BROWN R.A., HUNT W.F. Underdrain configuration to enhance bioretention exfiltration to reduce pollutant loads. J. Environ. Eng. 137, 1082, 2011.

13. JUNG K.Y., LEE K.L., IM T.H., LEE I.J., KIM S., HAN K.Y., AHN J.M. Evaluation of water quality for the Nakdong River watershed using multivariate analysis. Environ Technol Inno. 5, 67, 2016.

14. SINSABAUGH R.L., HILL B.H., FOLLSTAD SHAH J.J. Ecoenzymatic stoichiometry of microbial organic nutrient acquisition in soil and sediment. Nature. 468 (7320), 122, 2010.

15. REN C., KANG D., WU J.P., ZHAO F.Z., YANG G.H., HAN X.H., FENG Y.Z., REN G.G.. Temporal variation in soil enzyme activities after afforestation in the Loess Plateau, China. Geoderma. 282, 103, 2016.

16. QIN X.H., LIN X.R., XIANG X.Z., SONG T.Q., REN Q., HUANG Y., QIN Z. Soil enzyme activities and their relations with soil fertility in a tea plantation under straw mulching and white clover intercropping. Chinese Journal of Ecology. 28 (8), 1537, 2009 [In Chinese]

17. TROWSDALE S.A., SIMCOCK R. Urban stormwater treatment using bioretention. J. Hydrol. 397, 167, 2011.

18. DELAIRE C., DAS A., AMROSE S., GADGIL A., ROY J., RAY I. Determinants of the use of alternatives to arsenic-contaminated shallow groundwater: an exploratory study in rural West Bengal, India. J. Water Health. 15 (5-6), 799, 2017.

19. KAUSHAL S.S., GROFFMAN P.M., BAND L.E., ELLIOTT E.M., SHIELDS C.A., KENDALL C. Tracking nonpoint source nitrogen pollution in humanimpacted watersheds. Environ. Sci. Technol. 45, 8225, 2011.

20. LEFEVRE G.H., PAUS K.H., NATARAJAN P., GULLIVER J.S., NOVAK P.J., HOZALSKI R.M. Review of Dissolved Pollutants in Urban Storm Water and Their Removal and Fate in Bioretention Cells. J. Environ. Eng. 141 (1), 1, 2015.

21. LUBNOW F.S. Using Floating Wetland Islands to Reduce Nutrient Concentrations in Lake Ecosystems. National Wetlands Newsletter. 36 (6), 14, 2014.

22. LI L.Q., DAVIS A.P. Urban Storm-water Runoff Nitrogen Composition and Fate in Bioretention Systems.Environ. Sci. Technol. 48, 3403, 2015.

23. JIA Z., TANG S., LUO W., LI S., ZHOU M. Small scale green infrastructure design to meet different urban hydrological criteria, J. Environ Manage. 171, 92,2016.

24. State EPA of China (Ed.), China Environmental Science Press, Beijing, 2012 [In Chinese].
25. SMART M.M., RADA R.G., DONNERMEYER G.N. Determination of total nitrogen in sediments and plants using persulfate digestion. An evaluation and comparison with the Kjeldahl procedure. Water Res. 17, 1207, 1983.

26. State EPA of China (Ed.), China Environmental Science Press, Beijing, $4^{\text {th }}$ ed, 2002 [In Chinese].

27. MA Y.K., HE W.Y., ZHAO H.T., ZHAO J., WU X.W., WU W., LI X.Y., YIN C.Q. Influence of Low Impact Development practices on urban diffuse pollutant transport process at catchment scale. J Clean Prod. 213, 357, 2018.

28. EVANGELIOU N., GRYTHE H., KLIMONT Z., HEYES C., ECKHARDT S., LOPEZ-APARICIO S., STOHL A. Atmospheric transport is a major pathway of microplastics to remote regions. Nature Communications. 11, 3381, 2020.

29. MA Y., HAO S., ZHAO H., FANG J., ZHAO J., LI X. Pollutant transport analysis and source apportionment of the entire non-point source pollution process in separate sewer systems, Chemosphere. 21, 557, 2018.

30. HU Y.L., ZENG D.H., LIU Y.X., ZHANG Y.L., CHEN Z.H., WANG Z.Q. Responses of soil chemical and biological properties to nitrogen addition in a Dahurian larch plantationin Northeast China. Plant and Soil. 333, 81, 2010.

31. ALADAMAT R. Modelling Surface Water Susceptibility to Pollution Using GIS. Journal of Geographic Information System. 9 (3), 293, 2017.

32. TROWSDALE S.A., SIMCOCK R. Urban stormwater treatment using bioretention, J. Hydrol. 397, 167, 2011.

33. ISLAM M.A., ISLAM S., AKTER A., RAHMAN M.H. Effect of Organic and Inorganic Fertilizers on Soil Properties and the Growth, Yield and Quality of Tomato in Mymensingh, Bangladesh. Agriculture. 7 (3), 18, 2017.

34. KATSALIROU E., DENG S.P., NOFZIFER D.L., GERAKIS A. Long-term management effects on organic $\mathrm{C}$ and $\mathrm{N}$ pools and activities of $\mathrm{C}$-transforming enzymes in prairie soils,Eur. J. Soil Biol. 46, 335, 2010.

35. SHUH J., MING L.I., CHANG L., XING Z.K., ZHAO X. W., LIU H.M., CHENG L. Effect of Different Agroforestry Patterns on Soil Physi-Chemical Properties and Enzyme Activities. Chinese Journal of Soil Science. 45 (3), 648, 2014 [In Chinese].

36. ZHANG G.N., CHEN Z.H., ZHANG A.M., CHEN L.J. Effects of nitrogen deposition on typical hydrolytic enzyme activities by fluorimetric assay. Asian J. Chem. 25 (18), 10335, 2013.

37. JIAN S., LI J., CHEN J., WANG G.S., MAYES M.A., DZANTOR K.E., HUI D.F., LUO, Y.Q. Soil extracellular enzyme activities, soil carbon and nitrogen storage under nitrogen fertilization: A meta-analysis. Soil Biol. Biochem. 101, 32, 2016.

38. GENG Y., WANG D., YANG W. Effects of different inundation periods on soil enzyme activity in riparian zones in Lijiang. Catena. 149, 19, 2017. 